\title{
Memperkuat Peran Pemerintah Daerah: Mengelola Pariwisata Lokal Yang Berkelanjutan
}

\author{
I Gede Eko Putra Sri Sentanu', Mahadiansar ${ }^{2}$ \\ ${ }^{12}$ Program Studi Magister Ilmu Administrasi Publik, Fakultas Ilmu Administrasi. \\ Universitas Brawijaya, Kota Malang \\ sentanu@ub.ac.id, mahadiansar@student.ub.ac.id
}

\begin{abstract}
ABSTRAK
Tata kelola pariwisata akan berdampak kepada lingkungan yang dikendalikan oleh pemerintah daerah karena itulah pengembangan sector pariwisata menjadi penting dalam rangka meningkatkan kesejahteraan masyarakat dan ekonomi daerah. Dengan memperkuat peran pemerintah daerah sebagai leading sector pariwisata daerah, dianggap dapat mendorong terciptanya kolaborasi antar sector (actor) untuk mengelola pariwisata lokal yang berkelanjutan. Paper ini ditulis dengan tujuan untuk mengetahui seberapa jauh peran pemerintah daerah dan bagaimana hubungan antar sektor (actor) dalam mengelola pariwisata lokal yang berkelanjutan. Penelitian ini menggunakan pendekatan studi kepustakaan, dengan teknik pengumpulan data dokumentasi yang berasal dari telaah beberapa jurnal bereputasi, buku-buku dan sumber sekunder lainnya yang relevan dengan penelitian ini. Teknik analisis data adalah analisis konten. Dalam pengelolaan pariwisata maka peran tidak hanya dilakukan satu pihak tapi semua aspek pendukung yang terlibat dalam rangka menciptakan orkestrasi dan memastikan kualitas aktivitas, fasilitas, pelayanan, untuk menciptakan pengalaman dan nilai manfaat kepariwisataan sehingga memberikan keuntungan serta manfaat pada masyarakat hingga lingkungan, maka diperlukan pendorong sistem kepariwisataan melalui optimalisasi peran serta kolaborasi antara bussiness, government, community, academic, dan media.
\end{abstract}

Kata Kunci: Kolaborasi, Pemerintah Daerah, Pariwisata Berkelanjutan, Pariwisata Lokal.

\section{ABSTRACT}

Tourism governance will have an impact on the environment, which is controlled by local governments. The development of the tourism sector is essential to improve the welfare of the community and the regional economy. Strengthening the role of local government as a leading tourism sector in the region is considered to be able to encourage the creation of a collaboration between industries (actors) to manage sustainable local tourism. This paper was written to find out how far the role of local government is and how relations between sectors (actors) are in managing sustainable regional tourism. This study uses a literature study approach, with documentation data collection techniques derived from the study of several reputable journals, books, and other secondary sources that are relevant to this research. The data analysis technique is content analysis. In tourism management, the role is not only done by one party but all supporting aspects and involved in the framework of creating orchestration and ensuring the quality of activities, facilities, services, and to create experiences and value of tourism benefits to provide benefits to the community and the environment. These will be able to encourage the tourism system through the optimization of roles and collaboration between business, government, society, academics, and media.

Keywords: Collaboration, Regional Government, Sustainable Tourism, Local Tourism 


\section{PENDAHULUAN}

Pariwisata adalah suatu perjalanan yang dilakukan untuk sementara waktu, yang diselenggarakan dari suatu tempat ke tempat lain, dengan maksud bukan untuk berusaha atau bisnis atau mencari nafkah di tempat yang dikunjungi, tetapi semata-mata untuk menikmati perjalanan tersebut guna permasyarakatan dan rekreasi atau untuk memenuhi keinginan yang beraneka ragam. Pariwisata pada dasarnya merupakan merupakan produk aktivitas yang berupa pelayanan atas produk yang dihasilkan oleh industry pariwisata yang mampu menciptakan pengalaman perjalan bagi wisatwan. Selain dari pengertian di atas pariwisatajuga merupakan salah satu aspek yang berperan penting dalam meningkatkan pendapatan di setiap daerah. Pada Undang-Undang Nomor 10 Tahun 2009 Tentang Kepariwisataan menjelaskan bahwa kepariwisataan di perlukan untuk mendorong pemerataan, kesempatan berusaha dan memperoleh manfaat serta mampu menghadapi tantangan perubahan kehidupan lokal, nasional dan global. Sebagai salah satu aspek yang berpotensi dalam meningkatkan pendapatan daerah, pariwisata harus dikembangkan dengan baik. Untuk itu perlu adanya peran dari pemerintah dalam pengelolaanya.

Pengelolaan pariwisata harus merupakan pengelolaan yang terencana secara menyeluruh, sehingga dapat diperoleh manfaat yang optimal bagi masyarakat, baik dari segi ekonomi, sosial, dan kultural. Peran pemerintah dalam mengembangkan dan mengelola pariwisata secara garis besarnya adalah menyediakan infrastruktur (tidak hanya dalam bentuk fisik), memperluas berbagai bentuk fasilitas, kegiatan koordinasi antara aparatur pemerintah dengan pihak swasta, pengaturan dan promosi umum ke daerah lain maupun ke luar negeri. Pemerintah mempunyai otoritas dalam pengaturan, penyediaan, dan peruntukan berbagai infrastruktur yang terkait dengan kebutuhan pariwisata. Tidak hanya itu, pemerintah bertanggung jawab dalam menentukan arah yang dituju perjalanan pariwisata. Namun demikian, keberhasilan implementasi kebijakan sangat tergantung dari seberapa besar kompleksitas organisasi dan pihak-pihak yang terlibat didalamnya (Pratiwi, Saleh, \& Sentanu, 2019.

Kebijakan makro yang ditempuh pemerintah merupakan panduan bagi stakeholder yang lain di dalam memainkan peran masing-masing. Sebagaimana yang dimaksud dalam pasal 17 UU Nomor 10 Tahun 2009 bahwa Pemerintah dan Pemerintah Daerah wajib mengembangkan dan melindungi usaha mikro, kecil, menengah, dan koperasi dalam bidang usaha pariwisatadengan cara:

a) Membuat kebijakan pencadangan usaha pariwisata untuk usaha mikro, kecil, menengah, dan koperasi;

b) Memfasilitasi kemitraan usaha mikro, kecil, menengah, dan koperasi dengan usaha skala besar.

Model pelaksanaan pengembangan destinasi pariwisata daerah yang diusulkan untuk diterapkan dalam pengembangan potensi wisata yang ada di mengacu pada kondisi aktual saat ini berupa potensi dan wisata alam. Untuk mengembangkan wisata-wisata terdapat stakeholder yang teribat (pemerintah, lembaga non pemerintah), SDM, program-program, dana dan fasilitas. Berdasarkan keterlibatan stakeholders dan berdasarkan berdasar kondisi saat ini di dapatkan pogram-program yang diharpakan apat memberikan arahan yang jelas dalam upaya pengembangan daerah tujuan wisata di Kabupaten Tana Toraja ke depannya. 
Sasaran tersebut dapat tercapai melalui pengelolaan dan pengusahaan yang benar dan terkoordinasi, baik lintas sektoral maupuan swasta yang berkaitan dengan pengembangan dalam kegiatan pariwisata sehingga di perlukan dukungan serta peran dari masyarakat dan pemerintah dan seluruh sektor yang berperan kepariwisataan. Keberhasilan pelaksanaan pengembangan daerah tujuan wisata tidak terlepas dari peran semua elemen, tentunya dengan memperhatikan unsur program, anggaran dan proses yang sudah ada.

United Nation World Tourism Organization (UNWTO) (2013:12) mengatakan bahwa pariwisata adalah sektor kegiatan yang melibatkan banyak hubungan timbal balik di antara berbagai jenis aktor dan agen yang ikut campur dalam produksi barang dan jasa yang dikonsumsi oleh pengunjung. Di kerangka kerja ini, fungsi arahan pemerintah sangat penting dalam kondisi tersebut. khususnya relevan dalam mengoordinasikan upaya untuk membantu memastikan bahwa adanya dinamika pertumbuhan permanen pariwisata itu telah mencapai sampai saat ini secara ekonomi, sosial dan lingkungan yang berkelanjutan sehingga meningkat kontribusinya terhadap pembangunan.

Perkembangan pariwisata dapat dianalisis dan diteliti berdasarkan hubungan kolaboratif antara sektor publik dan swasta. Pariwisata mencakup kenyataan yang jauh lebih kompleks, karena sifatnya yang tersebar tanggung jawab untuk dalam pengembangannya, dibagikan karena mereka berada di sepanjang dan jaringan aktor yang dapat seperti yang diilustrasikan dalam uraian berikut:

1. Sektor swasta, sebagai penghasil utama dan pemasok barang dan jasa yang dikonsumsi oleh pengunjung, terdiri dari keragaman unit ekonomi yang ditentukan sebagai fungsi ukuran dan luasnya (usaha mikro, kecil, menengah dan besar, baik lokal, regional, nasional atau transnasional) terdiri dari berbagai bidang kegiatan produktif mulai dari manufaktur, perdagangan, transportasi, ke berbagai layanan (perhotelan, makanan dan layanan minuman, kegiatan budaya dan rekreasi, dll.), yang memberikan sedikit karakter terpisahpisah ke sektor pariwisata hipotetis.

2. Sektor publik, yang peran dasarnya berdasarkan fungsi dalam hal berbeda bidang kegiatan yang secara tegas mempengaruhi bagaimana pariwisata dikembangkan di suatu negara atau wilayah (pengembangan infrastruktur, perencanaan, kebijakan transportasi, masalah fiskal, pekerjaan, dll.) juga ditandai oleh beragamnya aktor dan agen yang hidup berdampingan di samping. Koeksistensi semacam itu terjadi dalam dua dimensi:

a. Secara horizontal, dalam hal legislatif (parlemen, kongres) dan / atau cabang eksekutif, umumnya melalui lebih dari satu kementerian atau departemen, agen, dll. Masingmasing dapat memiliki tanggung jawab untuk berbagai pariwisata terkait kegiatan di tingkat pemerintahan yang sama.

b. Secara vertikal, mengingat tingkat pemerintahan yang berbeda (lokal, regional, provinsi, nasional, dll.) yang ada di negara yang ditentukan, tergantung pada bentuk teritorial organisasi yang dimaksud (UNWTO, 2013:14-15).

Perhatian pada pengembangan kepariwisataan selama ini terfokus pada pengembangan dari sektor persektor, industri/swasta, pemerintah, masyarakat dan perkomponen produk pariwisata, pelayanan, pendukung, dan lain-lain. Padahal untuk menyediakan kualitas pengalaman yang terbaik dan menciptakan nilai yang tinggi bagi pengunjung, pengembangan sektor-sektor dan komponen-komponen tersebut harus bersinergi 
dalam satu rangkaian di sebuah destinasi, jadi tidak dapat berdiri sendiri (Emerson, Nabatchi, \& Balogh, 2011).

Perencanaan pariwisata sebagai perencanaan yang multi sektor dan multi aspek serta multi wilayah, maka dibutuhkan perencanaan kolaboratif sebagai proses menuju perencanaan yang terintegratif baik secara hirarki (Provinsi, Kabupaten, Kota) maupun secara sektor (berbagai kelembagaan/kementrian). Perencanaan kolaboratif sebagai proses menuju perencanaan yang terintegratif baik secara hirarki (Provinsi, Kabupaten, Kota) maupun secara sektor (berbagai kelembagaan/ kementrian).

Menurut (Mah \& Hills, 2012) seharusnya pariwisata berkelanjutan memperhatikan perencanaan kolaboratif atau collaborative planning dapat diwujudkan maka yang harus diperhatikan adalah:

a. Semua pihak yang terlibat bersedia membuka diri, sehingga muncul "trust" atau saling percaya di antara berbagai pihak yang akan berkolaborasi. Semua pihak harus terbuka, jujur, saling menghormati dan menghargai, sehingga tidak muncul konflik.

b. Pendekatannya harus kerja sama atau bersinergi, bkan berarti tidak ada kompetisi, kompetsi boleh ada tapi hars dijaga sebagai usaha untuk daya dorong mencapai tujuan bersama.

c. Setiap pihak memposisikan dirinya sama atau ada kesederajatan jadi tidak ada yang tinggi atau rendah, tetapi berbeda dalam peran, misal: pemerintah sebagai mediator, fasilitator dan legislator. Sedangkan swasta sebagai praktisi dan investor. Pengembangan kelembagaan tidak cukup hanya membentuk Dinas Pariwisata Provinsi/Kabupaten/Kota, tetapi yang lebih penting adalah sesuai dengan karakteristik sektor pariwisata yang multi sesktor dan multidimensi, diperlukan adanya wadah yang mempertemukan berbagai sektor tersebut.

Saat ini indonesia mengalami perkembangan yang cukup menjanjikan dikarenakan berbagai pengakuan dan penghargaan dari sektor pariwisata yang telah di raih oleh indonesia. Tahun 2018, data dari World Travel and Tourism Council (WTTC), indonesia berada pada rangking ke 9 dengan percepatan pertumbuhan wisatawan mancanegara tercepat di dunia, kemudian ditahun yang sama menteri pariwisata terpilih sebagai Best Ministry of Tourism katagori terbaik di kawasan Asia Fasifik. Tidak hanya itu saja, Bali juga dinobatkan destinasi wisata terbaik di dunia versi TripAdvisor. Kondisi ini bahwasanya indonesia memang memiliki pariwisata yang unggul dan di akui dunia dengan adanya berbagai prestasi di bidang pariwisata yang dihormati dunia. Penyebaran destinasi wisata perlu dibuat agar tetap berkelanjutan, dengan cara melakukan promosi serta pendekatan yang dikemas dalam bentuk kebudayaan ataupun pendekatan berupa diplomasi-diplomasi negara tetangga. Seperti misalnya event festival budaya, produk wisata yang ditawarkan dengan berbasis environmentalism demi kelangsungan destinasi lingkungan yang berkelanjutan.

Pengembangan pariwisata di indonesia memfokuskan pada ekosistem pariwisata dengan konsep framework 3 A yaitu Aktraksi, Aksesibilitas dan Amenitas dengan memperkuat sebanyak 7 dari 10 destinasi wisata berbasis bahari. Destinasi yang di maksud untuk mendukung peningkatan ekonomi sektor maritim dan sektor bahari dengan memperkuat pembangunan infrastruktur dengan collaborative governance melalui stakeholder terkait. Fasilitas pendukung seperti pengembangan desa wisata dan homestay 
dengan mengahdirkan seperti 10 Bali baru untuk memnunjang atraksi dan amenitas wisata yang berkelanjutan. Pencapaian 10 Bali baru yang ingin dicapai sangat pesat dengan melihat indikator keberhasilan tercatat kenaikan Pendapatan Asli daerah (PAD) seperti salah satu contoh di pariwisata Belitung dengan Kawasan Ekonomi Khusus (KEK) pariwisata Tanjung Kelayang yang naik 300\% selama 4 tahun terakhir. Program KEK pariwisata jugat turut menunjang kenaikan reealisasi investasi daerah pariwisata. Program 10 Bali Baru termasuk salah satu program prioritas dari Kementerian Pariwisata yang percepatan pembangunannya diharapkan dapat membantu mendatangkan 20 juta wisatawan mancanegara, jumlah tersebut sektor pariwisata dapat meraih devisa 17,6 miliar dollar AS atau setara dengan Rp 246,4 triliun di akhir penghujung 2019 (kompas.com, 2019).

Dengan peningkatan devisa yang signifikan, pemerintah republik indonesia melakukan 6 langkah kebijakan strategis nasional untuk meningkatkan devisa pariwisata diantaranya :

1. Mempercepat dalam penyelesaian infrastruktur pendukung; percepatan peyeesaian proyek infrastruktur pendukung bertujuan meningkatkan aksesibilitas kemudian mendukung peningkatan jumlah kunjungan wisatawan dari mancanegara

2. Mendorong perkembangan atraksi wisata; dengan tujuan memperluas di wilayah perbatasan atau crossborder tourism dengan mengelar event atraksi budaya lokal secara berkala

3. Meningkatkan kembali kualitas amenitas; melalui upaya percepatan pembebasan lahan

4. Memperkuat promosi wisata; dengan cara memperlama tinggal (length of stay) melalui promosi digital (marketplace), pengembangan paket wisata, perluasan paket promo (hot deals) di desinasi wisata yang menjadi regionel tourism

5. Mendorong investasi; dengan cara penerbitan publikasi standarisasi dan kegiatan usaha klasifikasi pengeluaran wisata manacnegara.

6. Menyusun standart manajemen pariwisata; menyusun standar manajemen krisis kepariwisataan dan membentuk forum manajemen krisis sejumlah daeerah dalam rangka untuk mengantisipasi dan membuat solusi secara bersama hingga terjadinya pemulihan pariwisata.

Tata kelola pariwisata akan berdampak kepada lingkungan yang dikendalikan oleh pemerintah daerah. Masalah dari tata kelola pariwisata yaitu pengembangan fasilitas pariwisata yang tidak akan terkontrol dengan baik dan kegiatan kepariwisataan memberikan dampak terhadap situs-situs warisan yang seharusnya dilestarikan. Kemudian dari sektor pengembangan infrastruktur akan mengancam keaslian pariwisata yang dimana disetiap daerah pasti akan berbeda. Faktor iklim yang ekstream dan bencana alam yang merusak lingkungan akibat tidak baiknya tata kelola pariwisata daerah. Pemerintah daerahpun sering menargetkan jumlah pengunjung yang banyak tanpa memikirkan daya tampung dalam setiap kunjungan pariwisata, pariwisata banyak menyediakan keuntungan yang lebih besar ketimbang masyarakat setempat.

Peluang yang didapatkan dari tata kelola pemerintahan daerah akan berdampak pada memberdayakan masyarakat lokal sebagai penjaga asli (seperti pemilik, pengelola, pendidik, pencerita) serta fasilitas warisan dunia secara aktif nantinya dalam kepariwisataan secara keberlanjutan seperti argowisata, ekowisata, dan wisata spiritual. Kemudian pengembangan 
baru dalam meningkatkan perekonomian masyarakat lokal seperti sistem pertanian, varietas lokal, kegiatan pasca panen dan wisata kuliner yang akan sangat terasa oleh masyrakat lokal. Pencatatan pariwisata di Indonesia akan dikenal melalui meningkatnya jumlah wisatawan dan lama tinggal yang dapat memberikan promosi lebih efektif di bidang pariwisata budaya dan argowisata menjadi patokan situs warisan dunia.

Abdurahman (2014:14) menyatakan bahwa fenomena kolaborasi tata kelola di Indonesia mulai berkembang, khususnya dimasa pasca reformasi. Masa orde baru identik dengan aplikasi pola pembangunan secara sentralistik yang mencerminkan akan pengelolaan direktif koordinatif (top down). Saat itu kekuatan koordinasi melalui Repelita (Rencana Pembangunan Lima Tahun) dianggap cukup efektif dalam mensinergikan sektor-sektor yang terkait dalam pembangunan. Namun pola pembangunan sentralistik ternyata tidak sanggup menghadapi arus globalisasi. Fenomena pengelolaan kolaboratif juga ditemui dalam konteks pembangunan kewilayahan di Indonesia, khususnya pasca reformasi. Telah dimaklumi, bahwa pelaksanaan otonomi telah menggiring daerah untuk melakukan berbagai terobosan pengelolaan kolaborasi tata kelola pariwisata di daerah. Untuk itu pentingnya aktor-aktor sosial yang terlibat dalam pengembangan pengetahuan baru demi mengembangkan produk pariwisata terintegrasi adalah fondasi untuk semua kerja sama dengan bermodalkan pemberdayaan sosial (Jakše, 2015).

Berikut ini contoh konsep kolaborasi tata kelola pariwisata di daerah provinsi Bali yang yang terlibat dalam kolaborasi yang dapat dilihat pada tabel dibawah ini :

Tabel 1 Contoh Aktor dalam Kolaborasi Tata Kelola Pariwisata Provinsi Bali Tahun 2016

\begin{tabular}{|c|c|c|}
\hline Lembaga Utama & Lembaga Pendukung & Agenda Tentang Kepariwisataan \\
\hline $\begin{array}{l}\text { Kementerian } \\
\text { Pendidikan } \\
\text { Kebudayaan }\end{array}$ & $\begin{array}{l}\text { - Badan Pelestarian Nilai Budaya: } \\
\text { Model Apresiasi Warisan Budaya } \\
\text { untuk Generasi Muda } \\
\text { - Dinas Kebudayaan (Provinsi dan } \\
\text { Kabupaten) } \\
\text { - Dinas Pariwisata (Provinsi dan } \\
\text { - Kabupaten) } \\
\text { - Forum Koordinasi } \\
\text { - Majelis Desa Adat }\end{array}$ & $\begin{array}{l}\text { Penjangkauan ke masyarakat } 11 \\
\text { kali pertahun (1 kali tingkat } \\
\text { provinsi, } 10 \text { kali di tingkat } \\
\text { kabupaten terdiri dari } 5 \text { kali di } \\
\text { SKPD dan } 5 \text { kali di masyarakat } \\
\text { lokal) }\end{array}$ \\
\hline $\begin{array}{l}\text { Kementerian Pariwisata } \\
\& \text { Dinas Kebudayaan } \\
\text { (Provinsi / Kabupaten) }\end{array}$ & $\begin{array}{l}\text { - } \text { LSM } \\
\text { - } \text { Kemerintah Provinsi dan } \\
\text { - Akademisi } \\
\text { - Media } \\
\text { - Sektor swasta } \\
\text { - Masyarakat lokal } \\
\end{array}$ & $\begin{array}{lcc}\text { Melakukan rapat koordinasi } & \text { dua } \\
\text { kali } & \text { setahun } & \text { dan } \\
\text { seminar sekali setahun } & \end{array}$ \\
\hline $\begin{array}{lr}\text { Dinas } & \text { Pedidikan, } \\
\text { Pemuda dan Olahraga } \\
\text { Provinsi }\end{array}$ & $\begin{array}{l}\text { - } L S M \\
\text { - } B P N B \\
\text { - } B P C B \\
\text { - Akademisi / universitas / sekolah }\end{array}$ & $\begin{array}{l}\text { Pelaksanaan sekali setahun di } \\
\text { Asosiasi Agen Pariwisata, sekali } \\
\text { setahun di Asosiasi Pemandu } \\
\text { Wisata, sekali setahun di Asosiasi } \\
\text { Restoran dan Hotel, sekali setahun } \\
\text { di Badan Promosi Pariwisata } \\
\text { Daerah, tiga kali setahun di } \\
\text { sekolah-sekolah,dan dua kali } \\
\text { setahun di perguruan tinggi }\end{array}$ \\
\hline
\end{tabular}




\begin{tabular}{|c|c|c|}
\hline Lembaga Utama & Lembaga Pendukung & Agenda Tentang Kepariwisataan \\
\hline Kementerian Pariwisata & $\begin{array}{l}\text { - Akademisi / universitas / sekolah } \\
\text { - LSM } \\
\text { - Kementerian Pendidikan dan } \\
\text { Kebudayaan (Program Pemandu } \\
\text { Wisata Khusus Warisan Budaya) }\end{array}$ & $\begin{array}{l}\text { Membentuk mekanisme dan } \\
\text { program } \\
\text { enam kali setahun }\end{array}$ \\
\hline Kementerian Pariwisata & $\begin{array}{l}\text { - Dinas Pariwisata Provinsi } \\
\text { - Badan Pemberdayaan } \\
\text { Masyarakat dan Pemerintah } \\
\text { Desa } \\
\text { - Dinas Perindustrian dan } \\
\text { Perdagangan } \\
\text { - Dinas Koperasi dan UKM }\end{array}$ & $\begin{array}{l}\text { Melakukan monitoring dan evaluasi } \\
\text { (monev) } \\
\text { sosialisasi empat kali setahun } \\
\text { (trimester) }\end{array}$ \\
\hline
\end{tabular}

Sumber : Data Olahan Peneliti, 2020

Pemerintah daerah dan pemerintah pusat diyakini memiliki sejumlah keunggulan dalam mengelola fenomena pariwisata yang kompleks karena kompetensi mereka di sejumlah bidang kebijakan terkait yang mempengaruhi pengembangannya, seperti contoh infrastruktur, tata ruang perencanaan, dan transportasi (Mowforth \& Munt, 2015). Suksesnya pengembangan pariwisata berkelanjutan salah satunya di London, UK mengidentifikasi sejumlah pendorong Keberhasilan sektor pariwisata turut mendorong pembuat kebijakan dalam upaya mereka menerapkan pariwisata berkelanjutan dengan kebijakan di tingkat daerah (Maxim, 2015). Kemudian pembangunan pariwisata berkelanjutan harus memanfaatkan SDA secara optimal sesuai daya dukung sehingga tidak menimbulkan kerusakan, menghormati sosial budaya setempat serta memastikan manfaat ekonomi yang berkelanjutan serta melibatkan stakeholder yang ada. kemudian (Burns \& Holden, 1997) mengatakan prinsipprinsip pembangunan pariwisata berkelanjutan adalah:

1) Menjaga kualitas lingkungan

2) Memberikan keuntungan kepada masyarakat lokal dan wisatawan

3) Menjaga hubungan, keharmonisan antara masyarakat lokal, kebutuhan wisatawan dan lingkungan

4) Menciptakan kondisi yang dinamis yang disesuaikan dengan carrying capasity

5) Stakeholder mempunyai misi yang sama terhadap akan pembangunan pariwisata berkelanjutan.

\section{METODE PENELITIAN}

Metode penelitian yang digunakan adalah studi kepustakaan (library research), dengan melakukan telaah terhadap sumber-sumber pustaka seperti buku-buku, jurnal ilmiah, laporan penelitian, dan dokumen lainnya baik cetak maupun online yang relevan dengan topik yang sedang dikaji pada penelitian ini. Studi kepustakaan merupakan serangkaian kegiatan yang berkenaan dengan metode pengumpulan data pustaka, membaca, dan mencatat serta mengolah bahan penelitian (Zed, 2014).

Pada penelitian ini menggunakan teknik pengumpulan data dokumentasi yang berasal dari berbagai macam jurnal bereputasi, buku-buku yang berhubungan dengan pengelolaan pariwisata daerah. Adapun teknik analisis data pada penelitian ini adalah analisis konten (content analysis). 


\section{HASIL DAN PEMBAHASAN}

\section{Tantangan Global dan Desentralisasi}

Pariwisata, merupakan salah satu hal yang menjadi primadona bagi seluruh negara, khususnya di Indonesia. Studi mencatat, 9\% PDB seluruh negara di dunia, selain bersumber dari sektor Pariwisatanya, banyak negara berlomba lomba untuk mendapatkan perhatian dunia dengan inovasinya digabungkan dengan potensi wisata yang ada di negaranya, hal ini demikian dilakukan karena mereka tersadar betul bahwasanya potensi pariwisata tidak hanya berdampak pada sisi perekonomian suatu daerah di sebuah negara, namun banyak faktor lain yang dapat dikembangkan setelah adanya icon pariwisata yang dibentuk di sebuah negara. Banyak negara yang saling berlomba lomba untuk dapat tergabung dalam World Seven Wonders, mereka begitu berambisi untuk menonjolkan wajah wisatanya di kancah dunia, mereka sadar betul akan wisata tidak hanya membantu mereka secara materil namun masih banyak dan lebih dari itu.

Kawasan ASEAN (Association of Southeast Asian Nations) sering disebut sebagai "surga wisata" di Asia karena memiliki kekayaan yang melimpah dalam hal pariwisata. Negara dengan tujuan utama pariwisata di ASEAN diantaranya Indonesia, Thailand, Malaysia, Singapura, dan Filipina. Untuk mendorong pertumbuhan sektor pariwisata di negara-negara ASEAN, salah satu upayanya yang dilakukan untuk tujuan tersebut adalah dengan diselenggarakannya ASEAN Tourism Forum (ATF) yang bertujuan untuk membuat ASEAN sebagai tujuan utama wisatawan (Effendi, 2010).

Selain itu dalam kapasitas sebagai upaya penyelenggaraan ASEAN perlu menghadirkan collaborative governance yang dimaknai sebuah hubungan kerjasama dihasilkan melalui kemitraan antara pemerintah, masyarakat dan pihak swasta karena mengingat kondisi pemerintah saat ini yang menjadi faktor utama dalam penyelesaian yang hadir di tengah masyarakat maka konsep kolaborasi pemerintah menjadi sangat penting. (Yudiatmaja, Safitri, \& Manalu, 2017:622). Definisi dari Desentralisasi menurut (Jha \& Mathur, 1999) secara umum merupakan sebuah penyerahan kewenangan dari pemerintah pusat dengan cara dekonstrasi perwakilan kantor wilayah atau dengan devolusi terhadap pejabat daerah maupun badan-badan daerah di setiap wilayah masing-masing.

Kemudian dampak kelemahan desentralisasi dalam tantangan global yaitu realitas masalah kepemimpinan kapabilitas dengan menyetarakan konsep collaborative governance antara pihak pemerintah, swasta dan publik yang seharusnya menjadi dalam pencapaian harapan desentralisasi itu sendiri (Setiawan, Samin, \& Mahadiansar, 2018) 
Dalam melakukan kunjungan, wisatawan mancanegara membutuhkan berbagai sarana dan prasarana yang mendukung. Hal ini menjadi salah satu faktor yang mempengaruhi tingkat kunjungan wisatawan mancanegara (Sri, 2013). Sebuah Organisasi Internasional bernama World Economic Forum (WEF) mengeluarkan beberapa indikator -indikator penilaian kinerja sektor pariwisata setiap negara atau disebut Travel \& Tourism Competitiveness Index (TTIC). Indeks TTIC mengukur bagaimana kebijakan yang diterapkan suatu negara dalam mendukung pembangunan dan keberlanjutan travel \& tourism (T\&T), yang akan memberikan daya tarik dan daya saing dalam pariwisata diantara negara-negara dunia.

Berdasarkan indeks TTIC Indonesia menempati peringkat ke-50 dunia dan peringkat ke-4 ASEAN dibawah Singapura, Malaysia, dan Thailand (World Economic Forum, 2015). Beberapa hal yang masih perlu dibenahi agar kinerja sektor pariwisata dapat meningkat diantaranya : sarana dan prasarana, pengelolaan sektor pariwisata seperti sumber daya manusia, serta kebijakannya. Banyak hal yang mendasar menjadi permasalahan pengelolaan pariwisata yang mempengaruhi minat dari wisatawan asing ke Indonesia. Kendati hal demikian, Indonesia masih dipandang primadona karena potensi yang dimilikinya

Dengan wilayah geografisnya, Indonesia memiliki potensi pariwisata yang amat kaya dan amat sangat disayangkan jika potensi yang sedemikian rupa terlewat begitu saja. Istilah tanah surga yang melekat pada Indonesia memang bukanlah sebagai isapan jempol belaka, sudah banyak riset dan studi yang membuktikan bahwasanya Indonesia memanglah sebuah negara yang tidak dapat diremehkan akan potensi wilayahnya. Namun potensi tersebut seakan akan tertutup oleh adanya masalah yang dapat dikatakan menahun dari potensi yang ada, sehingga penggalian dan pemberdayaan potensi wilayah tersebut menjadi kurang optimal, yang menjadi permasalahan pada sektor pariwisata di Indonesia agaknya adalah hal yang klise, yakni infrastruktur dan local wisdom yang sebenarnya menjadi sebuah daya tarik bagi wisatawan asing untuk datang mengunjungi sebuah hal yang cenderung unik bagi mereka.

Berdasarkan data Travel \& Tourism Competitivness Index (TTCI), Indonesia memiliki indikator paling rendah pada infrastructure dan natural and cultural resource. Aksesibilitas menjadi hal yang sangat penting dalam menjamin kenyamanan turis. Kurangnya aksesbilitas pariwisata dikarenakan banyak daerah yang belum menjadikan pariwisata sebagai leading sector serta kurangnya akses informasi. Cara meningkatkan aksesbilitas dapat dilakukan dengan pembangunan infrastruktur, seperti perbaikan jalan, ketersediaan transportasi dan rambu-rambu jalan, peningkatan sarana dan prasarana, serta peningkatan akses informasi melalui media internet seperti media sosial dan website resmi destinasi, dan loket informasi. 
Pembangunan infrastruktur tersebut dapat menstimulasi setiap terjadinya peningkatan kinerja sektor pariwisata Indonesia sehingga dapat bersaing dengan negara ASEAN lainnya, seperti Singapura dan Thailand. Motivasi yang mendorong orang untuk mengadakan perjalanan akan menimbulkan beberapa banyaknya permintaan - permintaan yang sama akan mengenai seperti prasarana dan sarana kepariwisataan jaringan telekomunikasi, akomodasi dan lain sebagainya. Dalam hal ini kesiapan sarana dan prasarana kepariwisataan merupakan salah satu faktor penentu berhasilnya pengembangan industri pariwisata daerah.

Terlebih ketika program otonomi telah diterapkan, maka masing-masing daerah dituntut untuk lebih memberikan perhatiannya pada penyediaan sarana prasarana kepariwisataan yang memadai dan paling tidak sesuai dengan standar intemasional. Indikator lemah lain yang dimiliki oleh Indonesia adalah sumber daya alam dan budaya (natural and cultural resource). Indonesia adalah negara yang kaya akan sumber daya alam dan keanekaragaman budaya. Faktor tersebut yang menarik turis untuk berkunjung.

Namun, Indonesia masih belum dapat menjaga keberlanjutan alam. Hal ini terlihat dari terjadinya kerusakan alam yang besar di Indonesia, seperti kebakaran hutan, hampir punahnya berbagai jenis satwa yang dilindungi (seperti orang utan) untuk tujuan bisnis tidak sehat. Faktor infrastruktur kurang memadai dalam hal aksesibilitas ini juga didukung dari faktor kegagalan pemerintah daerah maupun pusat dalam merencanakan sebuah program yang dapat meningkatkan aksesibilitas yang dimana berdampak pada diminati atau tidaknya sebuah objek wisata. Pemerintah seakan mengamini dalam kondisi sarana prasarana yang masih kurang memadai dan hal ini didukung oleh data rendahnya posisi Indonesia dalam Indeks pada ITTC.

Dari sisi SDM, kualitas pendidikan Indonesia yang rendah seakan-akan memanfaatkan potensi alam diolah dengan seadanya, kurangnya inovasi dengan ilmu yang seadanya akan berdampak pada hasil pengelolaan potensi alam yang kurang maksimal. Berdasarkan hasil uji secara acak pada 2 juta orang di 44 negara, Indonesia menempati posisi ke 34 dibanding Malaysia yang menempati urutan ke 9 dalam kemampuan Bahasa Inggris.

Sebuah tanggung jawab bersama, mengingat kemampuan berbahasa dan komunikasi dapat mempengaruhi banyak hal terutama wisatawan mancanegara yang menggunakan bahasa Inggris sebagai bahasa internasional atau bahasa ibu. Dari sisi akan publisitas pun demikian, permasalahan Indonesia adalah kalah dalam pemodalan untuk publikasi dibanding dengan negara-negara di ASEAN, kebijakan Indonesia dinilai masih belum dapat mengoptimalisasi sebuah potensi untuk diketahui oleh banyak orang. 


\section{Memperkuat Peran Pemerintah Daerah dalam Sektor Pariwisata}

Ruhanen (2013:92) menyatakan bahwa pemerintah daerah masih memiliki posisi terbaik untuk mendorong agenda pembangunan sektor pariwisata berkelanjutan untuk mencapai suatu tujuan yang di inginkan pemerintah pusat. Dalam hal meningkatkan pendapatan daerah melalui sektor pariwisata bukanlah hal yang mudah dengan melihat studi kasus yang berbeda-beda. Mengingat banyak hal yang perlu diperhatikan dalam pengembangan sektor pariwisata sehingga berdampak positif terhadap pendapatan daerah.

Salah satu hal yang perlu diperhatikan dalam pengembangan sektor pariwisata adalah peran pemangku kepentingan (stakeholders). Pemerintah adalah stakeholder yang memiliki peran penting dalam memajukan pengembangan sektor pariwisata. Peran penting tersebut terbentuk karena dalam pengembangan pariwisata, pemerintah memiliki fungsi sebagai pembuat kebijakan. Adapun peran pemerintah daerah sebagai upaya memperkuat peran pemerintah dalam pengembangan pariwisata menurut (Subadra, 2006) yang dikutip dalam (Afandi, Sunarti, \& Hakim, 2017) yaitu:

a. Perencanaan dan Pembangunan Pariwisata

(Conyers \& Hills, 1984) mendefinisikan perencanaan sebagai suatu proses yang berkesinambungan, yang mencakup keputusan-keputusan, atau pilihan-pilihan berbagai alternatif penggunaan sumberdaya untuk mencapai tujuan-tujuan tertentu pada masa yang akan datang. Perencanaan pembangunan sangat penting, mengingat, dengan perencanaan pembangunan, maka, akan mengangkat citra, potensi, dan daya saing suatu daerah. karena itu perencanaan pembangunan harus memiliki sistem agar perencanaan pembangunan tidak salah sasaran, dan tepat guna.

Perencanaan pembangunan dalam konteks pariwisata merupakan pondasi awal bagi pemerintah dalam mengambil peran yang penting dan strategis, mengingat pemerintah adalah pengambil keputusan, sehingga diharapkan akan terjadi peningkatan baik dalam segi sarana dan prasarana maupun aksesibilitas. Adapun yang menjadi fokus dalam perencanaan pembangunan pariwisata oleh pemerintah adalah :

1. Peningkatan Daya Tarik Wisata;

2. Penyediaan Fasilitas Rumah Makan;

3. Peningkatan Aksesibilitas; dan

4. Promosi Wisata

b. Kebijakan dan Peraturan Pariwisata 
Kebijakan merupakan salah satu produk yang dikeluarkan oleh pemerintah sebagai upaya untuk memberikan legitimasi atau ketetapan dan ketentuan terhadap suatu hal yang diperdebatkan atau hendak dibahas. Dalam hal ini, kebijakan pariwisata merupakan strategi kedua yang penting pula sebagai upaya pengembangan sektor pariwisata yang hendak dilakukan oleh pemerintah. Mengingat dengan adanya kebijakan dalam sektor pariwisata maka akan ada regulasi atau peraturan yang sah secara hukum untuk melindungi sekaligus mengembangkan pariwisata.

Oleh karena itu, regulasi yang merupakan otput dari kebijakan pariwisata harus diperkuat dan diperjelas agar tidak terjadi tumpang tindih regulasi, sekaligus yang perlu diperhatikan adalah bahwa regulasi pariwisata harus mampu untuk memberikan kemudahan bagi investor, dan para wisatawan sehingga mau untuk menanamkan modal dan berkunjung, sehingga berdampak terhadap pembangunan daerah.

Peran pemerintah dalam pembangunan pariwisata begitu penting, mengingat tanpa pemerintah maka sektor pariwisata suatu daerah tidak akan mampu terkelola dengan baik, karena pemerintah adalah stakeholder yang memiliki peranan paling besar terhadap kemajuan sektor pariwisata pada suatu daerah yang akan berdampak terhadap pendapatan daerah. Salah satu negara yang memiliki potensi luar biasa dalam pengembangan sektor pariwisata adalah Jepang.

Kemudian (Rosliana 2017) dalam tulisannya menyatakan Jepang merupakan negara yang maju di Kawasan asia, dan memiliki perkembangan yang pesat dalam perkembangan teknologi informasi dan komunikasi. Pada tahun 1990-an, Jepang kemudian bangkit setelah perekonomiannya turun dengan membenahi sektor perekonomiannya. Pembenahan perekonomian pada saat itu, dilakukan dengan fokus terhadap sektor industri, perbankan, transportasi dan telekomunikasi. Baru pada tahun 2007 Pemerintah Jepang mulai fokus terhadap pengembangan sektor pariwisata sebagai strategi dalam penguatan perekonomian.

Pada tahun 2015 Pemerintah Jepang membuat program tour yaitu program "Muslim Friendly". Adapun strategi yang dilakukan oleh pemerintah Jepang sebagai upaya dalam pengembangan sektor pariwisata yaitu:

1. Penggunaan Website Wisata Berbahasa Asing;

2. Menyediakan Tujuan Wisata; dan

3. Kemudahan Perjalanan Wisata. 
Berdasarkan strategi yang dilakukan oleh Pemerintah Jepang dalam pengembangan dan pengelolaan sektor pariwisata, maka titik penting yang harus dilakukan oleh Indonesia adalah dengan melalui penguatan teknologi informasi dan komunikasi, serta pelayanan wisata. Mengingat kedua strategi tersebutlah yang membuat Jepang mengalami perkembangan yang pesat dalam sektor pariwisata.

\section{Fungsi Dan Tanggung jawab Stakeholder Untuk Manajemen Pariwisata}

Pada proses pengembangan dan manajerial sebuah potensi pariwisata, tidak semerta merta dilakukan oleh satu pihak, dibutuhkan kerjasama dari berbagai pihak demi menciptakan iklim kerjasama yang baik. Salah satu strategi yang dicanangkan pemerintah dalam pengembangan pariwisata adalah melalui penggunaan kolaborasi Model Pentahelix. Model Pentahelix diperkenalkan dan dituangkan ke dalam Peraturan Menteri (Permen) Pariwisata Republik Indonesia Nomor 14 Tahun 2016 Tentang Pedoman Destinasi Pariwisata Berkelanjutan bahwa untuk menciptakan orkestrasi dan memastikan kualitas aktivitas, fasilitas, pelayanan, dan untuk menciptakan pengalaman dan nilai manfaat kepariwisataan agar memberikan keuntungan dan manfaat pada masyarakat dan lingkungan, maka diperlukan pendorong sistem kepariwisataan melalui optimalisasi peran bussiness, government, community, academic, dan media (BGCAM). Konsep BGCAM oleh Fosler (2002) lebih lanjut dijelaskan sebagai berikut:

a. Business (swasta/dunia usaha).

Berperan sebagai penyelenggara bisnis pariwisata sesuai etika bisnis, profesional, bertanggung jawab dan berkelanjutan. Peran dunia usaha sebagai lembaga yang "profit oriented” juga harus ikut bertanggung jawab dalam keberlanjutan lingkungan sebagai modal utama pariwisata. Kemitraan swasta dengan masyarakat dan pemerintah sangat diperlukan dalam arti yang "sebenarnya". Hubungan yang saling menguntungkan (winwin) harus dibangun dengan pola-pola pendekatan yang formal maupun non formal. Beberapa destinasi pariwisata yang berhasil melibatkan banyak pihak, salah satu karena membangun pendekatan non formal antara swasta dan pemerintah.

b. Government (Pemerintah).

Pemerintah berperan menyiapkan prasarana dan sarana dasar mendukung pengembangan pariwisata, menyiapkan berbagai peraturan berkaitan dengan pariwisata, memfasilitasi kemudahan berwisata dan berusaha dan melakukan kegiatan promosi dan pemasaran destinasi. Peran Pemerintah Daerah dalam pengembangan destinasi adalah sebagai: regulator, fasilitator, mediator dan penyedia prasarana. Dalam pengembangan destinasi 
maupun pengembangan industri memerlukan regulasi yang jelas dan bijak serta kelembagaan yang padu baik dari pihak swasta maupun pemerintah. Dalam ketergantungan tersebut dapat diidentifikasikan pembagian peran atau siapa melakukan apa. Pengembangan industri atau usaha pariwisata tentunya dilakukan oleh swasta dan pemerintah berfungsi memfasilitasi dan mendukungnya. Pemerintah Provinsi bersama Pemerintah Pusat dan Kabupaten maupun Kota yang bertugas mengembangkan masyarakat dan berbagai macam pelayanan publik yang diperlukan agar pariwisata dapat terselenggara ditempat tersebut dan industri kepariwisataannya dapat berkembang. Selain itu pemerintah berperan langsung dalam pengembangan regulasi untuk mengatur, mengendalikan kegiatan pengembang dan industri, serta memperkuat kelembagaan untuk peningkatan kapasitas dalam merumuskan kebijakan dan pengambilan keputusan di berbagai tingkatan pemerintahan

c. Community.

Community yang dimaksud ini adalah masyarakat dan komunitas-komunitas (NGO/LSM); masyarakat berperan mendukung sapta pesona/darwis plus menyediakan jasa pariwisata/ekonomi kreatif. Masyarakat adalah obyek dan subyek dari pariwisata itu sendiri, tapi di sisi lain masyarakat bis amenjadi kendala pengembangan pariwisata di suatu destinasi. Oleh sebab itu masyarakat harus tahu persis apa peran mereka dan pariwisata adalah untuk kesejahteraan. Pendampingan terus menerus dari pemerintah, LSM dan swasta dapat meningkatkan peran masyarakat dalam pengembangan pariwisata daerah.

d. Academician (Akademisi).

Akademisi berperan melakukan berbagai riset dan pengabdian masyarakat berkaitan pengembangan pariwisata, agar pembangunan pariwisata berbasis penelitian. Seringkali peran hasil penelitian tidak dimanfaatkan dalam pengembangan pariwisata. Berbagai pengabdian masyarakat dapat dilakukan akademisi dalam pengembangan pariwisata, untuk itu diperlukan komunikasi dan kerjasama dengan akademisi dalam pengembangan pariwisata.

e. Media.

Terutama media online, saat ini menjadi kekuatan informasi dan andalan dalam promosi pariwisata. Promosi dan pemasaran pariwisata sekarang dapat dilakukan dengan cepat dengan memanfaatkan media sosial. Promosi sekarang lebih bersifat inklusif, contoh: wisatawan dapat mengunggah testimony berkunjung ke suatu obyek wisata di media sosial. 
Dalam pengelolaan pariwisata maka peran tidak hanya dilakukan satu pihak tapi semua aspek pendukung dan yang terlibat. Selama ini paradigma yang berkembang adalah pengelolaan hanya dilakukan oleh pemerintah, namun sebenarnya pengelolaan harus dilakukan oleh semua pihak seperti swasta dan masyarakat juga. Pemerintah selaku pengawas harus diimbangi swasta selaku investor dan juga masyarakat yang mempunyai pandangan kongkrit lapangan dalam pengelolaan pariwisata.

Hal ini juga pemerintah tidak boleh mendominasi dan adanya hirarki struktur pengelolaan sehingga membuat pihak masyarakat merasa dijadikan kaki tangan pemerintahan. Koordinasi kemitraan koordinasi yang dilakukan oleh pihak pemerintah terhadap pengelolaan pariwisata dilakukan setiap 1 tahun sekali. Hal tersebut dengan adanya sosialisasi ini mengharapkan pihak mitra faham dengan tugas pelaksanaan program pengelolaan pariwisata yang dimana koordinasi ini dilakukan atas dasar pencapaian tujuan bersama yaitu pencapaian peningkatan Pendapat Asli Daerah. Sebagai mana Dinas Pariwisata, Pemuda dan Olahraga mempunyai tugas melaksanakan Pemerintah Daerah terkait Bidang Pariwisata, Pemuda dan Olahraga.

\section{Strategi Pengelolaan Pariwisata Daerah yang Berkelanjutan}

(Dharmiasih et al., 2012) dalam sebuah laporannya tentang strategi pengelolaan pariwisata di Provinsi Bali menyatakan pariwisata akan menjaga dan melindungi keaslian situs warisan dunia terhadap budaya berlandaskan filosofi Tri Hita Karana, dengan memperlihatkan cara merefleksikan pembangunan yang harmonis melibatkan konservasi pariwisata berkelanjutan yang didukung oleh stakeholder secara pro aktif, menyediakan bentuk pengalaman pengunjung yang nyata dan memberikan manfaat bagi masyarakat daerah dengan konsep pengelolaan pariwisata daerah yang berkelanjutan. Adapun bukti nyata yang harus dilakukan untuk mencapai strategi pengelolaan pariwisata daerah yang ada di Indonesia sebagai berikut :

1. Strategi dengan menghadirkan semua stakeholder mempunyai pemahaman serta apresiasi tentang nilai-nilai dalam mempromosikan pelestarian dan perlindungan situs-situs warisan budaya yang berkelanjutan. Untuk mencapai tujuan tersebut di perlukan beberapa implementasi kebijakan yang harus dibuat diantaranya :

a. Merealisasikan program tepat sasaran kepada masyarakat daerah kepada stakeholder di masing-masing daerah untuk membangun opini sebuah kesadaran dan kepentingan secara bersama mengenai pariwisata, Dengan demikian meningkatkan jiwa memiliki, apresiasi dan rasa tanggung jawab terhadap pariwisata yang berkelanjutan.

b. Mempromosikan secara berkala tentang warisan budaya sebagai identitas daerah dengan menghadirkan lokakarya kepada masyarakat daerah serta merangkul 
mendapatkan gambaran sebagai upaya mempertahankan dan memperkuat identitas daerah hingga terciptanya pembangunan ekonomi melalui partisipasi yang proaktif.

c. Mempresentasikan warisan dunia kepada masyarakat daerah dan stakeholder oleh Dinas Kebudayaan dari tingkat kabupaten/kota melalui forum diskusi kebudayaan.

d. Mengajak mahasiswa, akademisi dan praktisi pariwisata untuk belajar serta memahami situs pariwisata sehingga adanya pemahaman kebudayaan tentang warisan dunia.

e. Menyusun mekanisme interpretasi yang jelas tentang situs warisan dunia, dengan nilainilai serta kearifan lokal sehingga dapat mendidik ataupun memberdayakan masyarakat daerah dan pemandu wisata demi memberikan informasi yang akurat kepada pengunjung wisatawan.

2. Memastikan pembangunan sebagai sarana dan fasilitas pendukung (infrastuktur, perumahan), agar dapat melestarikan keaslian budaya pariwisata berkelanjutan. Hal ini diupayakan untuk mengurangi dampak negatif terhadap pelestarian lingkungan. Kemudian memperkuat kebijakan pengunaan lahan dan pengelolaan pegawasan situs melalui kerjasama secara kolaboratif dan partisipasif yaitu dengan cara :

a. Menyebarkan program pendidikan dan peningkatan kapasitas terhadap setiap kelompok ataupun organisasi stakeholder agar bertanggung jawab terhadap lingkungan.

b. Membangun sistem monitoring sesuai dengan aturan yang berlaku di tingkat lokal hingga nasional, dan untuk mengamanatkan perlindungan daerah konservasi SDA hingga menegakkan aturan-aturan daerah kepariwisataan mengenai hukum pengembangan wisata.

c. Meningkatkan sistem pengelolaan air untuk menjaga dan melindungi stabilitas pemasukan air, sehingga pengelolaan air bisa dilakukan secara efesien dan efektif. Kemudian tidak ada dialih fungsikan ke industri pariwisata maupun lokasi geografis lainnya serta menjamin bahwa kepentingan air terutama untuk pariwisata dapat dibatasi dan dikontrol sehingga air dapat diprioritaskan.

d. Mengutamakan upaya pelestarian seperti perlindungan, pemanfaatan budaya bagi semua stakeholder dan melaksanakan penilaian terhadap dampak lingkungan / AMDAL serta penilaian warisan terdahulu sebelum melakukan dalam pembangunan infrastruktur sarana prasarana.

3. Memberdayakan masyarakat lokal untuk terlibat secara langsung dalam pengelolaan pariwisata berkelanjutan, demi meningkatkan kesejahteraan masyarakat lokal dengan melibatkan beberapa unsur yaitu : 
a. Setiap organisasi atau kelompok memiliki perspektif atau cara pandang yang berbeda untuk itu dapat melakukan diskusi tentang identitas wisata melalui forum resmi, kemudian untuk mendapatkan kesepakatan bersama terkait masa depan tentang situs warisan budaya agar bisa memastikan partisipasi lebih bermanfaat.

b. Mencari pemimpin organisasi atau kelompok yang bisa membimbing, mempengaruhi, mengkoordinasi dengan upaya memperlihatkan kemampuan dan bakat individual untuk mengenali unsur nilai warisan budaya (material dan non material) dari situs melalui mapping budaya di daerah tersebut.

c. Mendidik dan memberdayakan masyarakat lokal dalam meningkatkan sebagai peran dan pemahaman serta mempromosikan tentang konsep pariwisata yang berkelanjutan.

d. Memperkuat materi pendidikan mulai dari sekolah dasar dengan mengintegrasikan nilai pariwisata yang berkelanjutan kemudian memberikan dukungan (beasiswa, pelatihan, loka karya, branding, pencipta/pengembangan produk, kesehatan, homestay, dst) untuk masyarakat lokal agar bermanfaat dalam meningkatkan produktifitas hidup dan kesejahteraan sosial.

e. Menciptakan sebuah kerjasama (collaborative governance) baik dari sektor publik maupun sektor privat untuk meningkatkan kesejahteraan masyarakat lokal dengan adanya pariwisata berkelanjutan.

4. Meningkatkan pengelolaan bagi pengunjung demi memberikan dampak signifkan kepada pengunjung pariwisata diantaranya :

a. Pengelola pariwisata berkelanjutan adalah penjaga asli sebagai bentuk memberdayakan masyarakat lokal. Kemudian mengukur daya tampung dengan kajian penilaian untuk memperkuat sistem pariwisata sebagai warisan dunia.

b. Merumuskan rencana pengelolaan pengunjung dan melakukan penilaian serta merumuskan rencana manajemen krisis dan resiko sebagai pertimbangan sebelum membuka situs untuk dipublikasikan

c. Memulai manajemen pariwisata dengan mengimplementasikan unsur pesona wisata dengan memberikan perencanaan infrastruktur rehabilitasi infrastruktur secara berkala untuk mendukung pariwisata berkelanjutan di situs warisan dunia.

d. Membuat paket wisata dan pola kunjungan untuk meningkatkan kualitas hidup masyarakat lokal serta mengawasi kawasan lindung yang menjadi tujuan wisata berkelanjutan. Seperti contoh paket wisata standart internasional memiliki pengaturannya dari United Nation World Tourism Organization (UNWTO) yaitu : 
1) Pre-arranged Tour merupakan perjalanan wisata membuat perencanaan dan diatur sebelum melakukan kunjungan. Baik dari segi fasilitas maupun kebutuhan yang mendasar dalam perjalanan wisata.

2) Package Tour dimana suatu pilihan kunjungan wisata yang nantinya mereka kunjungi sesuai dengan keinginan wisatawan agar menikmati kemudahan dalam perjalananya

3) Coach Tour sebuah perjalanan yang eskslusif yang dimana perjalanan wisata yang dilakuak secara rutin yang telah ditetapkan yang dipimpin oleh pemandu wisata profesional.

4) Special Arranged Tour perjalanan wisata yang disusun secara khusus guna memenuji permintaan seorang langganan atau lebih sesuai dengan kepentingannya

5) Optional Tour dimana suatu perjalanan wisata tambahan diluar pengaturan yang telah disusun dan diperjanjikan pelaksanaannya, yang dilakukan atas permintaan wisatawan itu sendiri.

\section{PENUTUP}

Pengembangan kawasan wisata menjadi isu yang kompleks dimana dalam pengkajiannya dibutuhkan pendekatan multidimensional, baik secara fisik, ekonomi, sosial budaya dan juga politik. Tidak dapat dipungkiri bahwa adanya pengembangan kawasan wisata atau yang dikenal dengan industri pariwisata akan memberikan dampak secara langsung terhadap kondisi masyarakat. Pada umumnya pengembangan kawasan wisata dijadikan sebagai sektor andalan untuk mendorong pertumbuhan ekonomi, peningkatan pendapatan daerah, pemberdayaan perekonomian masyarakat, perluasan lapangan kerja dan kesempatan berusaha bagi warga masyarakat.

Pembangunan tentang pariwisata memerlukan perhatian dan komitmen dari semua aktor termasuk pemerintah daerah, yaitu kolaborasi antar aktor, antar sektor dan antar lini secara berkelanjutan dan terintegrasi. Hal ini dapat terwujud jika pemerintah daerah dan pemangku kepentingan (stakeholders) menjalankan kebijakan dan perannya secara konsisten dan tertuang pada program dan kegiatan daerah melalui strategi pariwisata berkelanjutan. Strategi yang mendukung tindakan kolaboratif antara para stakeholder dalam perlindungan, pelestarian dan pemanfaatan situs warisan dunia sebagai sebuah tujuan yang sangat di prioritaskan. Selain itu masyarakat harus mempunyai kesadaran baik secara kelompok maupun individu pentingnya wisata terahadap daerahnya dengan menghubungkan unsurunsur bussiness, government, community, academic, dan media 
Tujuanya agar adanya strategi dalam menetapkan program yang rinci, anggaran serta upaya realisasi pada pengembangan pariwisata berkelanjutan demi pembangunan sarana dan prasarana sangat penting untuk mewujudkan target pemerintah khususnya devisa Negara. Strategi pariwisata yang berkelanjutan ini akan ditinjau melalui pemantauan berkala dan proses evaluasi yang melibatkan instansi pemerintah sebagai pembuat kebijakan; dan masyarakat setempat, LSM dan akademisi sebagai aktor. Hasilnya akan menentukan sebuah perubahan potensial yang perlu dilakukan di dalam strategi. Seluruh stakeholder diundang untuk bisa berpartisipasi secara aktif dalam pengelolaan pariwisata berkelanjutan di setiap daerah yang ada di Indonesia.

\section{DAFTAR PUSTAKA}

Abdurahman, B. (2014). Destination management organization (DMO); Diskursus konsep dasar tata kelola kawassan pariwisata dalam konteks collaborative governance di Indonesia. Jurnal Kepariwisataan Indonesia, 9(2), 1-21.

Afandi, A., Sunarti, \& Hakim, L. (2017). Peran pemerintah daerah dalam pengembangan destinasi wisata bahari pulau gili noko kabupaten gresik ( studi pada dinas kebudayaan , pariwisata , pemuda dan olahraga kabupaten gresik ). Jurnal Administrasi Bisnis, 49(1), 117.

Burns, P. M., \& Holden, A. (1997). Alternative and sustainable tourism development the way forward. The Earthscan Reader in Sustainable Tourism. Earthscan. London.

Conyers, D., \& Hills, P. J. (1984). An introduction to development planning in the third world. America: John Wiley \& Sons Australia.

Dharmiasih, W., Sayoga, A., Pradipta, A., Arbi, Y., Christensen, C. S., DeeBrine, P., ... Sapardan, W. (2012). Strategi pariwisata berkelanjutan. Provinsi Bali.

Emerson, K., Nabatchi, T., \& Balogh, S. (2011). An integrative framework for collaborative governance. Journal of Public Administration Research and Theory, 22(1), 1-29.

Jakše, L.-M. C. (2015). Connecting social actors in developing integrated tourism products. Journal of Universal Excellence, 4(1), 1-16.

Jha, S. N., \& Mathur, P. C. (1999). Decentralization and local politics. SAGE Publishing. New Delhi, India.

Mah, D. N. Y., \& Hills, P. (2012). Collaborative governance for sustainable development: Wind resource assessment in Xinjiang and Guangdong Provinces, China. Sustainable Development, 20(2), 85-97.

Maxim, C. (2015). Drivers of success in implementing sustainable tourism policies in urban areas. Tourism Planning and Development, 12(1), 37-47.

Mowforth, M., \& Munt, I. (2015). Tourism and sustainability: development, globalisation and new tourism in the third world (4th ed.). London: Taylor and Francis Inc.

Pratiwi, K. R. I., Saleh, C., \& Sentanu, I. G. E. P. S. (2019). Policy implementation of tour guides license in maintaining the quality of tourism in bali province. Journal of Indonesian Tourism and Development Studies, 7(3), 175-183.

Rosliana, L. (2017). Wisata budaya sebagai alat penguat ekonomi di jepang. Kiryoku Jurnal Studi Kejepangan, 1(1), 10.

Ruhanen, L. (2013). Local government: facilitator or inhibitor of sustainable tourism development? Journal of Sustainable Tourism, 21(1), 80-98.

Setiawan, R., Samin, R., \& Mahadiansar. (2018). Dampak desentralisasi terhadap kapabilitas kepala daerah; Studi kasus gubernur riau periode tahun 2008-2013. Jurnal Ilmu 
Administrasi Negara (JUAN), 6(2), 15-24.

Sri, A. P. A. (2013). Faktor-faktor yang memotivasi perempuan sebagai pengelola pondok wisata di kelurahan ubud kecamatan ubud kabupaten gianyar. Jurnal Analisis Pariwisata, 1, 1-10.

Subadra, I. N. (2006). Ekowisata hutan mangrove dalam pembangunan pariwisata berkelanjutan : Studi kasus di mangrove information center, desa pemagon, kecamatan denpasar selatan, kota denpasar. Udayana.

Yudiatmaja, W. E., Safitri, D. P., \& Manalu, A. M. R. (2017). Inovasi kebijakan dan pemerintahan jaringan di era desentralisasi : Studi kasus perda kota batam no 4 tahun 2015. Prosiding SNaPP, 7(3), 612-631.

Zed, M. (2014). Metode penelitian kepustakaan (3rd ed.). Jakarta: Yayasan Obor Indonesia.

\section{Dokumen}

Undang-Undang Nomor 10 Tahun 2009 Tentang Kepariwisataan

Undang-Undang Nomor 14 Tahun 2016 Tentang Pedoman Destinasi Pariwisata Berkelanjutan

UNWTO (United Nation World Tourism Organization) 2013. Governance for The Tourism Sector and its Measurement

\section{Internet}

6-Langkah Kebijakan Pemerintah Peningkatan Devisa Pariwisata (19 Maret 2019) (n.d.) $\begin{array}{lllll}\text { Diperoleh pada } & \text { Desember } & \text { 30, } & \end{array}$ https://travel.kompas.com/read/2019/03/19/110700827/6-langkah-pemerintahtingkatkan-devisa-pariwisata-indonesia

Sektor Pariwisata ditargetkan Raup Devisa Rp 246 Triliun di 2019 (28 Juli 2019) (n.d.) Diperoleh pada Desember 30, 2019 dari https://money.kompas.com/read/2019/07/28/172200726/sektor-pariwisataditargetkan-raup-devisa-rp-246-triliun-di-2019- 